\title{
Apples for Oranges: Disparities in Offset Legislation and Policy among Jurisdictions and its Implications for Environmental Protection and Sustainable Development in Australia
}

\author{
Linda Abdo (Corresponding author) \\ School of Arts and Sciences, The University of Notre Dame, Australia \\ PO Box 1225, Fremantle, Western Australia 6959 \\ Tel: 61-408-090-931_E-mail: linda.abdo@westnet.com.au \\ Sandy Griffin \\ INPEX Operations Australia Pty Ltd \\ 144 Wickham Point Road, Wickham, Northern Territory, Australia \\ Tel: 61-889-243-118Ｅ-mail: ecoserv@bordernet.com.au
}

\begin{abstract}
Annabeth Kemp
School of Arts and Sciences, The University of Notre Dame, Australia

PO Box 1225, Fremantle, Western Australia 6959
\end{abstract}

Tel: 61-894-330-263 E-mail: annabeth.kemp@nd.edu.au

Received: December 23, 2018 Accepted: January 11, 2019 Published: February 11, 2019

doi:10.5296/emsd.v8i1.14081ＵRL: https://doi.org/10.5296/emsd.v8i1.14081

\begin{abstract}
As a signatory to Agenda 21, the Rio Declaration on Environment and Development, the 2030 Agenda for Sustainable Development (including the Sustainable Development Goals) and the Convention on Biological Diversity, Australia has an international obligation to ensure sustainable development. Biodiversity offsets are one tool used by Australian regulators to allow development to continue, whilst ensuring international obligations for
\end{abstract}


sustainable development are met. In this study, legislation, policy and published guidelines for the Australian Commonwealth, states and territories were analysed to determine if the application of biodiversity offsets was consistent with the principles of sustainable development (environmentally, socially, economically) and if the allowance of biodiversity offsets in different jurisdictions created gaps in biodiversity and environmental protection across Australia. Regulation of biodiversity offsets was found to be inconsistent between the Commonwealth and the states and territories, with most jurisdictions having less than 50\% similarity. This inconsistency in offset policy and legislation between jurisdictions could lead to loss of biodiversity. Additionally, jurisdictions did not adequately consider the social and economic aspects of sustainability in relation to biodiversity offsets, meaning that, through the allowance of biodiversity offsets, Australia may not be meeting their international obligations related to sustainable development. Further legislative development for biodiversity offsets is required in Australia to improve environmental protection and to adequately consider all aspects of sustainability. The Council of Australian Governments is a mechanism that could be used to ensure all jurisdictions consider the aspects of sustainability consistently in relation to biodiversity offsets.

Keywords: Offset, Biodiversity, Sustainable development, Environmental policy, Environmental legislation, Environmental condition

\section{Introduction}

Since 1992, Australia has demonstrated a long-term commitment to sustainable development, as one of the more than 178 countries agreeing to the United Nations Agenda 21 and the Rio Declaration on Environment and Development. This led to Australia implementing the National Strategy for Ecologically Sustainable Development in December 1992. The goal of this strategy is to ensure "development that improves the total quality of life, both now and in the future, in a way that maintains the ecological processes on which life depends" (Ecologically Sustainable Development Steering Committee, 1992). In addition to this, Australia was one of more than 150 countries that agreed to adopt the 2030 Agenda for Sustainable Development, which also includes the aspirational Sustainable Development Goals (SDG). Under this Agenda, Australia has voluntarily committed to undertake a review to evaluate its performance on sustainable development. While sustainable development is not generally included as provisions in the legislation and policies of Australian jurisdictions, it is largely stated in objects and mandatory consideration clauses. This means that Australian legislation and policy must be interpreted with an underlying lens that ensures sustainable development (Macintosh, 2015). However, as the assessment of sustainability to meet the SDGs is complex and inconsistent (Allen, Metternicht, \& Wiedmann, 2018; Pope, Bond, Hugé, \& Morrison-Saunders 2017), it is uncertain if the implementation of sustainable development in Australia is comprehensive.

The International Institute for Sustainable Development provides the most commonly used definition of sustainable development being: "development that meets the needs of the present without compromising the ability of future generations to meet their own needs" (International Institute for Sustainable Development, 2017). Within the scope of sustainable 
development, the equal consideration of environmental, social and economic aspects is required to ensure that the current level of natural capital is maintained (Gibson, 2009; Moldan \& Dahl, 2007; International Institute for Sustainable Development, 2017; Macintosh, 2015). This balance of aspects is also captured in the Rio Declaration on Environment and Development, along with the actions in Agenda 21 and the SDGs. Therefore, as a signatory to these international agreements, Australia has committed to ensuring sustainable development and the balance between these three aspects.

Biodiversity offsets, also known as 'Environmental offsets', are now recognised as one tool to ensure that developments are undertaken in an ecologically sustainable way (Fallding, 2014). However, if biodiversity offsets are to be used to ensure development is sustainable, then environmental, social and economic aspects of the biodiversity offset must also be considered. Protecting biological diversity from development impacts through biodiversity offsetting was first introduced by way of wetland compensation requirements in the United States of America in the 1970's (Benabou, 2014; Burgin, 2008). Although the definition of biodiversity offsets can vary (Fallding, 2014), the International Finance Corporations (IFC) Performance Standard 6 defines biodiversity offsets as "measurable conservation outcomes resulting from actions designed to compensate for significant residual adverse biodiversity impacts arising from project development and persisting after appropriate avoidance, minimisation and restoration measures have been taken" (IFC, PS6). This IFC performance standard contributes to the assurance of sustainable development and is required for all corporations to secure and maintain ongoing funding from global banks. As these banks provide finance for the larger developments projects globally, these performance standards are required of almost all large-scale projects around the world. While this provides some level of surety that developments will be sustainable, the performance standards are not prescriptive and the level of conformance to and consistency in application of these standards is unknown.

Throughout Australia, jurisdictions have agreed to developments with predicted significant impacts on the environment on the condition that they deliver biodiversity offsets (e.g. Burton, Rogers, \& Richert, 2016; Coggan, Buitelaar, Bennett, \& Whitten, 2013; Kujala, Whitehead, Morris, \& Wintle, 2015; May, Hobbs, \& Valentine, 2017), in an attempt to ensure that the environmental principles of sustainable development are not compromised. However, the implementation of biodiversity offsets may change the use and/or function of an area, and while environmental aspects may be improved, secondary social and economic impacts may occur, such as changes in land use (Lim, Carrasco, McHardy, \& Edwards, 2017), displacement (Ghosh, 2017), and unemployment and poverty (Ali, Kennedy, Kiesecker, \& Geng, 2018). Therefore, Australian requirements for biodiversity offsets need to include explicit consideration of economic and social impacts in addition to environmental impacts to ensure that their use is not compromising the principles of sustainable development. If this is not the case, then Australia may be creating social and economic inequalities, and may also be remiss in meeting their international agreements. 


\subsection{Biodiversity Offset Requirements in Australia}

Biodiversity offsets in Australia are required through provisions in environment-related legislative acts, regulations, and/or policy as result of a statutory environmental impact assessment process. While each of the three levels of government in Australia (Commonwealth (Cwlth), State and Territory, and Local (Municipal)) has the ability to enforce environmental laws at some level, typically it is only the Cwlth and State and Territory governments that require some form of biodiversity offsets.

The Australian Constitution is the primary legal document giving powers to the Cwlth, however, without explicit reference to the environment in the Constitution, the Cwlth has no specific environmental power, and the protection of the environment is the primary responsibility of the Australian states and territories. They may choose to legislate in order to carry out their environmental duties or to delegate responsibilities to local governments. Local governments only have responsibility for the environment if this is delegated to them by the states or territories, and can utilise biodiversity offsets to fulfil these responsibilities. Generally, this is related to local amenity or nuisance.

This omission of specific reference to the environment in the Constitution was, in combination with historical context, a recognition that the states and territories exercised power over their natural resources (Peel \& Godden, 2005). Instead the Cwlth has a responsibility towards 'external affairs' under Section 51 (xxix) of the constitution and thus derives its ability to make laws and policies for environmental protection from Australia's signature to various international agreements, e.g. the Convention on Biological Diversity (CBD).

This allows the Cwlth, along with the states and territories, to have extensive powers to regulate environmental matters, which has the ability to cause overlap and conflict. However, as the states and territories have historically always sought to maintain their role in regulating their own environmental matters (Peel \& Godden, 2005), the Inter-governmental agreement on the environment (IGAE) was developed in 1992 to avoid potential legal conflicts and to set the roles and responsibilities in regards to the environment at each level of government (Commonwealth of Australia, 1992).

In 1997, the roles and responsibilities for the environment were further described in the Heads of Agreement (HoA), that was developed by the Cwlth, states and territories through Council of Australian Governments (COAG). Specifically, the HoA limits the role of the Cwlth to the protection of several key areas: Matters of National Environmental Significance (MNES) and environmental assessment and approvals. Additionally, it allows for the Cwlth and the states and territories to develop bilateral agreements, whereby a State or Territory may undertake an environmental assessment and/or approval on behalf of the Cwlth (Council of Australian Governments, 1997). While the IGAE and HoA do not specifically mention biodiversity offsets, they do broadly denote the roles and responsibilities of the Cwlth, states and territories in relation to the environment. As such, these roles and responsibilities also extend to biodiversity offsets. 


\subsection{The Consequence of Statutory Heterogeneity}

There is a lack of international standards on biodiversity offsets (Benabou, 2014), meaning that each country and jurisdiction within each country develops rules around biodiversity offsets independently. This lack of consistency can result in a failure to meet conservation goals at regional, national or international scales (Bull, Suttle, Gordon, Singh, \& Milner-Gulland, 2013). While the IGAE mandates that the states and territories cannot cause adverse effects in another jurisdiction, if environmental legislation and policy relating to biodiversity offsets are not comprehensive in prescribed outcomes and do not adequately consider social and economic aspects, then Australia may, therefore, not be meeting its international obligations to ensure sustainable development.

With the Cwlth having overarching responsibility for sustainable development and the states and territories having responsibility for all environmental matters within their jurisdiction, theoretically the principles of sustainable development should be included and consistently applied in legislation and policy for biodiversity offsets throughout Australia. However, in the absence of a nationally integrated framework for biodiversity offsets this may not be the case. The aim of this research is to determine if the principles of sustainable development are comprehensive and integrated into biodiversity offsets in Australia. This will be assessed through:

1. Determining if environmental policy and legislation related to biodiversity offsets in Australia is sufficiently comprehensive across jurisdictions to ensure that no substantial gaps exist in biodiversity and environmental protection.

2. Determining if the use of biodiversity offsets includes adequate consideration of environmental, social and economic aspects such that Australia can meet their international obligations related to sustainable development.

Given that the legislation and policy of each jurisdiction has been developed through a democratic political process with likely different priorities, and that the Cwlth has developed the Environment Protection and Biodiversity Conservation Act 1999 (EPBC Act) to focus on MNES, it is expected that gaps in environmental protection may be found. Furthermore, as legislation and policy has been developed to protect the environment specifically, and that consideration of the three aspects of sustainability are rarely integrated (Gibson, 2009), it is expected that social and economic aspects may have not been adequately considered and, consequently, requirements for biodiversity offsets may be compromising the achievement of truly sustainable development.

\section{Methods}

Current legislation, policy and published guidelines stated by the Cwlth and each Australian State and Territory as being related to biodiversity offsets were reviewed (Table 1), and analysed for the inclusion of sections applicable to biodiversity offsets. As the role of local governments in environmental regulation is delegated by the states and territories, local government by-laws were not included in the analysis. 
Table 1. List of environmental legislation and policy reviewed

\begin{tabular}{|c|c|c|}
\hline Jurisdiction & Reference & Legislation/policy reviewed \\
\hline \multirow{3}{*}{ Commonwealth } & \multirow{3}{*}{$\begin{array}{l}\text { Department of the } \\
\text { Environment and } \\
\text { Energy, } 2018\end{array}$} & $\begin{array}{l}\text { Environment Protection and Biodiversity Conservation } \\
\text { Act } 1999\end{array}$ \\
\hline & & $\begin{array}{l}\text { Environment Protection and Biodiversity Regulations } \\
2000\end{array}$ \\
\hline & & $\begin{array}{l}\text { Environment Protection and Biodiversity Conservation } \\
\text { Act } 1999 \text { Environmental Offsets Policy } 2012\end{array}$ \\
\hline \multirow[b]{2}{*}{$\begin{array}{l}\text { Australian Capital } \\
\text { Territory }\end{array}$} & \multirow[b]{2}{*}{$\begin{array}{l}\text { Environment, } \\
\text { Planning and } \\
\text { Sustainable } \\
\text { Development } \\
\text { Directorate, } 2018\end{array}$} & Planning and Development Act 2007 \\
\hline & & ACT Environmental Offsets Policy \\
\hline \multirow{5}{*}{ New South Wales } & \multirow{5}{*}{$\begin{array}{l}\text { Office of } \\
\text { Environment and } \\
\text { Heritage, } 2017\end{array}$} & Biodiversity Conservation Act 2016 \\
\hline & & $\begin{array}{l}\text { Local Land Services Act } 2013 \text { (as amended by the Local } \\
\text { Land Services Amendment Act 2016) }\end{array}$ \\
\hline & & Biodiversity Conservation Regulation 2017 \\
\hline & & Local Land Services Regulation 2014 \\
\hline & & $\begin{array}{l}\text { State Environmental Planning Policy (Vegetation in } \\
\text { Non-Rural Areas) } 2017\end{array}$ \\
\hline \multirow[b]{2}{*}{ Northern Territory } & \multirow{2}{*}{$\begin{array}{l}\text { Northern Territory } \\
\text { Environmental } \\
\text { Protection } \\
\text { Authority, } 2013\end{array}$} & Environmental Assessment Act \\
\hline & & $\begin{array}{l}\text { Guidelines on environmental offsets and associated } \\
\text { approval conditions }\end{array}$ \\
\hline \multirow{3}{*}{ Queensland } & \multirow{3}{*}{$\begin{array}{l}\text { Queensland } \\
\text { Government, } 2018\end{array}$} & Environmental Offsets Act 2014 \\
\hline & & Environmental Offsets Regulation 2014 \\
\hline & & $\begin{array}{l}\text { Queensland Environmental Offsets Policy (Version 1.6): } \\
\text { June } 2018\end{array}$ \\
\hline \multirow{4}{*}{ South Australia } & \multirow{4}{*}{$\begin{array}{l}\text { Department for } \\
\text { Environment and } \\
\text { Water, } 2017\end{array}$} & Native Vegetation Act 1991 \\
\hline & & Native Vegetation Regulations 2017 \\
\hline & & $\begin{array}{l}\text { Guide for calculating a Significant Environmental Benefit } \\
\text { under the Native Vegetation Act } 1991 \text { and the Native } \\
\text { Vegetation Regulations } 2017\end{array}$ \\
\hline & & $\begin{array}{l}\text { Policy for calculating a Significant Environmental } \\
\text { Benefit under the Native Vegetation Act } 1991 \text { and the } \\
\text { Native Vegetation Regulations } 2017\end{array}$ \\
\hline \multirow{5}{*}{ Tasmania } & \multirow{5}{*}{$\begin{array}{l}\text { Department of } \\
\text { Primary } \\
\text { Industries, Water } \\
\text { and Environment, } \\
2002 \text {; }\end{array}$} & Forest Practices Act 1985 \\
\hline & & Nature Conservation Act 2002 \\
\hline & & Threatened Species Protection Act 1995 \\
\hline & & Water Management Act 1999 \\
\hline & & Natural Resource Management Framework \\
\hline
\end{tabular}




\begin{tabular}{|c|c|c|}
\hline & $\begin{array}{l}\text { Forest Practices } \\
\text { Authority, 2011; }\end{array}$ & $\begin{array}{l}\text { Guidelines for Natural Values Surveys - Terrestrial } \\
\text { Development Proposals }\end{array}$ \\
\hline & $\begin{array}{l}\text { Natural and } \\
\text { Cultural Heritage } \\
\text { Division, } 2015\end{array}$ & $\begin{array}{l}\text { Policy of the Forest Practices Authority: The use of } \\
\text { offsets }\end{array}$ \\
\hline \multirow{3}{*}{ Victoria } & \multirow{3}{*}{$\begin{array}{l}\text { Environment, } \\
\text { Land, Water and } \\
\text { Planning, } 2018\end{array}$} & Planning and Environment Act 1987 \\
\hline & & $\begin{array}{l}\text { Guidelines for the removal, destruction or lopping of } \\
\text { native vegetation }\end{array}$ \\
\hline & & $\begin{array}{l}\text { A quick comparison of first party and third party offset } \\
\text { sites }\end{array}$ \\
\hline \multirow{4}{*}{ Western Australia } & \multirow{4}{*}{$\begin{array}{l}\text { Environmental } \\
\text { Protection } \\
\text { Authority, } 2018\end{array}$} & Environmental Protection Act 1986 \\
\hline & & WA Environmental Offsets Policy 2011 \\
\hline & & WA Environmental Offset Guidelines \\
\hline & & $\begin{array}{l}\text { Bilateral Agreement under section } 45 \text { of the } \\
\text { Environmental Protection and Biodiversity Conservation } \\
\text { Act } 1999\end{array}$ \\
\hline
\end{tabular}

From the analysis, the different biodiversity offset requirements related to sustainable development (i.e. environmental, social, economic) for the listed legislation, policies and published guidelines were recorded (Table 2). The legislation, policy and published guidelines for each jurisdiction was then reanalysed against these requirements to create a presence/absence table of sustainable development considerations for biodiversity offsets for each jurisdiction. It should be noted that only aspects included in legislation, policy and published guidelines currently in effect were included in the analysis. Historical and draft legislation, policy and published guidelines were outside the scope of this analysis, as were additional aspects that might be required by jurisdictions as conditions of approval, but not specifically stated in legislation and policy.

The presence/absence data was analysed using the PRIMER statistical software package (Clarke, Gorley, Somerfield, \& Warwick, 2014). The Jaccard resemblance measure was used to compare similarities of jurisdictions. A dendrogram was used to visualise the level of similarity among jurisdictions. The group-average was used for the dendrogram, depicting the similarity between jurisdictions as the mean closeness of two groups, averaging over all between-group pairs.

\section{Results}

The legislative acts for all Australian jurisdictions allow governments to require biodiversity offsets through some mechanism. All jurisdictions were found to require biodiversity offsets in certain circumstances with the exception being the Northern Territory, which currently cannot consider biodiversity offsets as part of an environmental impact assessment under the Environmental Assessment Act (Northern Territory Environmental Protection Authority, 2013). However, most jurisdictions do not have biodiversity offset specific legislation, instead requiring biodiversity offsets as a condition of an approval to compensate for residual impacts to the environment. Queensland was the only jurisdiction that has an act specifically 


\section{Macrothink}

designed to consider biodiversity offsets. NSW has a section of the Biodiversity Conservation Act 2016 that is dedicated to biodiversity offsets.

All Australian jurisdictions assessed where similar in the requirement for biodiversity offsets as the final step in the application of all or most of the mitigation hierarchy of avoid, reduce, rehabilitate/restore, offset. This is consistent with the standards put forward by the Business and Biodiversity Offsets Program (BBOP; Business and Biodiversity Offsets Programme, 2018).

In terms of subsidiary legislation or policy, eight of the nine Australian jurisdictions had other legislation and/or policy that related specifically to biodiversity offsets, with a total of six statutory documents (three regulations and three policies) and a further eight non-statutory frameworks, policies and guidelines in place.

In 2007, South Australia was the first jurisdiction to implement policy that specifically refers to biodiversity offsets, although this is non-statutory. Western Australia was the first jurisdiction to implement a statutory biodiversity offsets policy in 2011 (Figure 1).

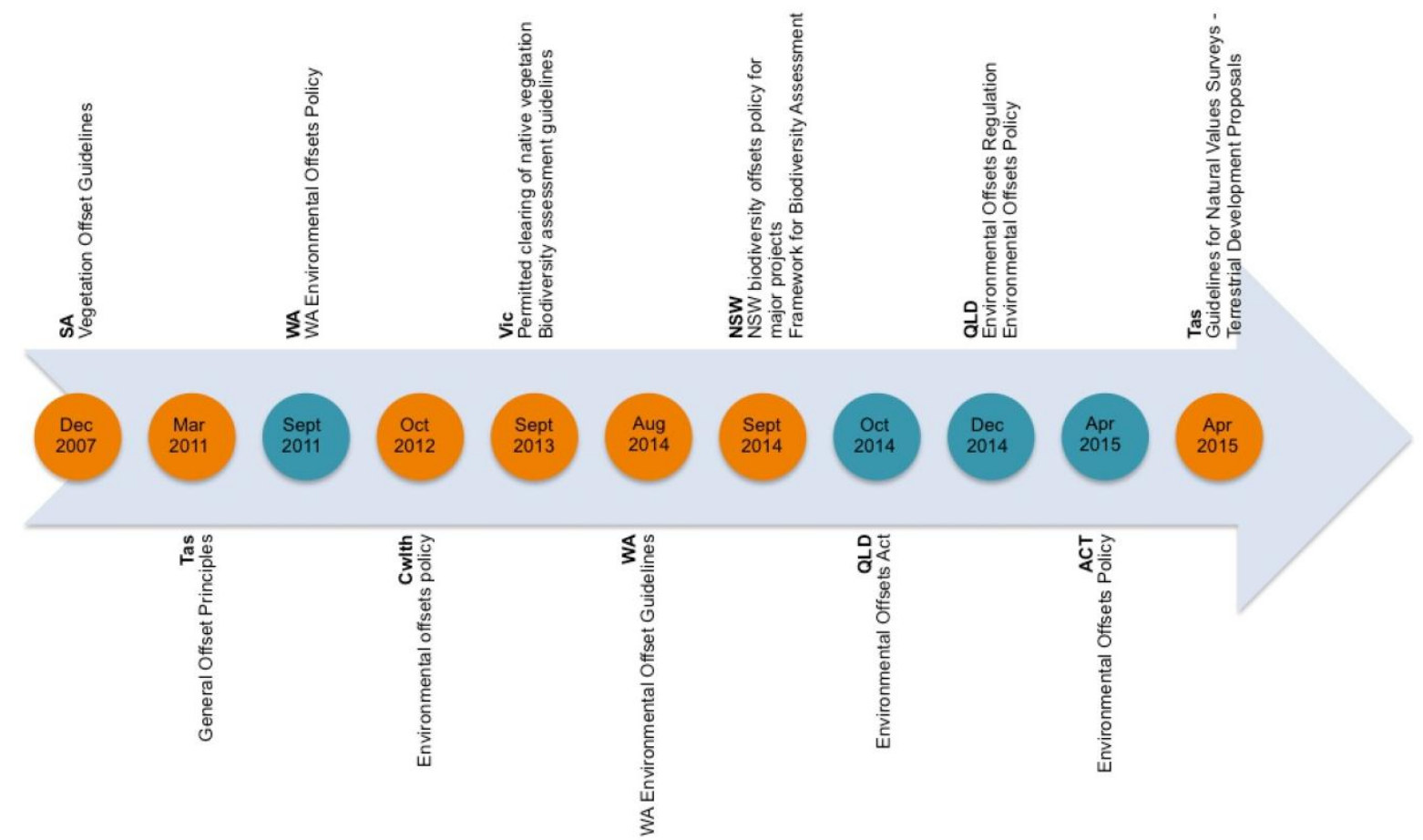

Figure 1. Timeline of implementation of biodiversity offset specific legislation and policies in Australia. Orange circles represent non-statutory documents, Blue circles represent statutory documents. ACT - Australian Capital Territory, Cwlth - Commonwealth, NSW New South Wales, Qld - Queensland, SA - South Australia, Tas - Tasmania, Vic - Victoria, WA - Western Australia

While Victoria only introduced guidelines including biodiversity offsets in 2013, it should be noted that in 2002 it developed the cross-departmental strategy "Victoria's native vegetation management: a framework for action". This now superseded framework provided principles related to the clearing of native vegetation for use by the several Victorian departments and 
agencies responsible for the care of native vegetation areas, including natural resources and in catchments (Department of Sustainability and the Environment, 2003). This framework included provision for government to consider achievement of no net loss through biodiversity offsets. As this framework is not currently in effect, it was not included within the scope of this analysis.

\subsection{Biodiversity Offset Aspects in Legislation and Policy}

The review of legislation, policy and published guidelines found the wording of the various requirements for biodiversity offsets was different among jurisdictions. These different requirements were, however, grouped together into themes that are explored more fully below. With this in mind, the analysis identified 11 environmental aspects, 4 social and 3 economic aspects related to biodiversity offsets.

\subsubsection{Environmental}

Broad-scale biodiversity offset requirements for all removal of native vegetation (E_2) or for all impacts on species and/or communities contained in appended lists (listed matters; E_3)) were included in legislation and policies of several jurisdictions. Other legislation, policies and published guidelines included specific definitions of matters that must be considered in terms of biodiversity offsets (E_1), contrasting with those that did not include these matters, whereby the requirements for matters to be offset were more discretionary.

One jurisdiction (ACT) specified in legislation and policy timeframes in which biodiversity offsets must be delivered (E_4), while others either do not require this or may require timeframes as part of conditions placed on certain developments (outside the scope of this analysis).

The legislation, policy and published guidelines of all jurisdictions except for Tas and NT required biodiversity offsets to be "like-for-like"," meaning that the matters to be offset must be the same (species and/or ecological communities) as those required to be compensated for (E_10). In addition to this, many jurisdictions required that biodiversity offsets must be designed to provide compensation that at least maintains (or improves) the viability of the species or community expected to be impacted, or to provide enhancements that match (or better) that which was lost/the scope of the adverse biodiversity impacts (no net loss or net gain; E_5).

Other considerations of various legislation, policies and published guidelines were for biodiversity offsets to be undertaken by third parties on behalf of developers (delegated; E_7) and/or to be delivered in various stages through the construction and/or operation of a development (staged; E_11).

Some jurisdictions allowed for advanced offsets, where credit of past appropriate conservation/rehabilitation/restoration work could be credited towards a developer and used to offset future impacts of development (E_9).

Several jurisdictions also allowed for consideration of indirect biodiversity offsets, being measures that improve knowledge, understanding and management of environmental values 
leading to improved conservation outcomes (E_8).

A biodiversity offsets calculator was provided by several jurisdictions as a way of ensuring that biodiversity offsets were designed to deliver adequate compensation. An offset calculator is a type of interactive database that would calculate either levels of compensation required or provide a level of assurance that the proposed compensation would be adequate.

\subsubsection{Social}

Several jurisdictions included social considerations through inclusion of specific appeal processes for developers $\left(S \_1\right)$ and communities (S_2), or through the requirement for community consultation in relation to biodiversity offsets $\left(\mathrm{S} \_3\right)$.

\subsubsection{Economic}

Economic considerations were included in legislation, policies and published guidelines in several ways. Land-holders can create biodiversity credits that can then be on-sold to developers. Developers can purchase and retire these credits in order to fulfil biodiversity offset conditions (tradeable permits; Ec_1).

Some jurisdictions also offer conservation funds through which developers can provide payments as an alternative to directly funding biodiversity offset programs (Ec_2). The money in these funds is then used by the government of that jurisdiction to undertake conservation projects of its discretion.

The impact of biodiversity offset requirements on the developer is an important consideration when incorporating the concept of sustainable development. Although this was not explicitly considered in any of the legislation, policies or published guidelines reviewed, it was indirectly considered through the use of biodiversity offset calculators that incorporated financial impacts.

\subsection{Legislation and Policy Review}

\subsubsection{Commonwealth (Cwlth)}

The Cwlth government requires biodiversity offsets for 'significant impacts' on MNES that are described by the EPBC Act. Biodiversity offsets under the EPBC Act relate to more than 2000 protected matters, including more than 1800 threatened species and ecological communities (Miller et al., 2015). The EPBC Act is administered by the Department of the Environment and Energy (DEE). Although not statutory, DEE has developed a biodiversity offset policy (Department of Sustainability, Environment, Water, Population and Communities, 2012a), which is a guideline and accompanying biodiversity offset calculator (E_6) that assists developers in proposing biodiversity offsets that will be acceptable to accompany applications for environmental approvals. The offsets calculator, developed as an offsets assessment guide for the Cwlth, assesses the annual probability of extinction of species/communities expected to be impacted utilising figures published by the "Red List", a global list of threatened species that is curated by the non government organisation 'International Union for the Conservation of Nature' (IUCN) (Department of Sustainability, 
Environment, Water, Population and Communities, 2012b).

As described by the Environment Protection and Biodiversity Conservation Act 1999 Environmental Offsets Policy 2012, the Cwlth conditions biodiversity offsets for significant impact to any EPBC Act listed matter (MNES) (E_1, E_3). These biodiversity offsets should be "like-for-like" (E_10) and ensure there is no net loss of biodiversity (E_5). The Cwlth allows for biodiversity offsets to be delegated (E_7) and staged (E_11), and also allows for advanced (E_9) and indirect (E_8; termed "other compensatory measures") biodiversity offsets.

While social aspects are considered as part of the environmental impact assessment process, and by default any biodiversity offsets that might have been proposed in an environmental impact statement, consideration of social aspects were not required specifically for biodiversity offsets. As such, no social aspects of biodiversity offsets were noted as required.

Economic aspects were not specifically required for biodiversity offsets either. The financial impact on the developer was, however, included as a requirement as this is considered as part of the offsets calculator (Ec_2). While there is not a formal appeals process for developers and concerned stakeholders, the EPBC act allows for interested persons to seek injunctive relief or to initiate judicial review of decisions of the Minister, meaning that developers and/or community members can appeal biodiversity offset conditions through court. However, as this is not a dedicated appeal process, this has been omitted from the analysis.

\subsubsection{Australian Capital Territory (ACT)}

The legislative framework in the ACT requires biodiversity offsets under the Planning and Development Act 2007 for ACT-protected matters, as well as MNES listed under the EPBC Act (E_1, E_3), as conditions of development approvals. Within the ACT, the statutory ACT Environmental Offsets Policy (ACT Government Environment and Planning, 2015) provides further detail as to specific biodiversity offset requirements.

The ACT legislation and policy requires biodiversity offsets to be "like-for-like" (E_10) and to ensure no net loss (E_5). Biodiversity offsets can be delegated (E_7) and proposals for advanced (E_9) and indirect (E_8) biodiversity offsets may be accepted. The ACT also considers appeals from developers $\left(S_{-} \_1\right)$ and concerned stakeholders (S_2). While community consultation is required for prescribed development proposals, it is not comprehensive and consequently has not been included in the analysis.

\subsubsection{New South Wales (NSW)}

In NSW, biodiversity offsets are required under the Biodiversity Conservation Act 2016, the Local Land Services Act 2013 (as amended by the Local Land Services Amendment Act 2016) and the State Environmental Planning Policy (Vegetation in Non-Rural Areas) 2017, which are administered by the Office of Environment and Heritage (OEH). Biodiversity offsets are required for most impacts on biodiversity caused by major projects and are established through either retiring biodiversity credits (only where credits are available for the listed matters impacted (i.e. like-for-like)), undertaking biodiversity conservation actions or 
mine-site rehabilitation (where applicable), or through payment into the Biodiversity Conservation Fund, where the payment required is calculated using the Offset Payments Calculator and is commensurate with the value of biodiversity credits that would have been purchased.

The Biodiversity Conservation Act 2016 requires biodiversity offsets for residual impacts on listed species and ecological communities, that are listed within Schedules 1 and 2. It also requires biodiversity offsets for areas of "outstanding biodiversity value" that are declared through publication on the NSW legislation website (E_1 and E_3). This includes areas that had been previously declared as critical habitat under the Threatened Species Conservation Act 1995.

Retiring of biodiversity credits must be undertaken prior to the commencement of actions that would impact on listed matters (E_4), although these may be staged throughout development (E_11). The NSW legislation and policy requires biodiversity offsets to be "like-for-like", except where an approved variation is in place. It also allows for biodiversity offset requirements to be delegated to third parties (E_7), for indirect biodiversity offsets to be implemented (E_8), and for developers to provide a financial contribution to the government in lieu of a biodiversity offset (Ec_2). The NSW legislation and policy allows for appeals in relation to enforcement matters, but not in regards to the setting of biodiversity offset conditions, and as such has not been included in the analysis.

\subsubsection{Northern Territory (NT)}

The NT government does not have in place specific biodiversity offset legislation or policy and can not consider biodiversity offsets (Northern Territory Environmental Protection Authority, 2013).

The NT government had previously drafted biodiversity offset guidelines but these were withdrawn prior to formalisation after a change of governing party in 2012. Even though NT cannot currently legally require biodiversity offsets, they have developed voluntary biodiversity offset projects with some developers of larger scale developments (e.g. INPEX, 2012). However, as these are not required, these have not been included in the analysis.

\subsubsection{Queensland (Qld)}

Qld is the only state to have developed specific biodiversity offset legislation. Qld biodiversity offsets are required for significant residual impacts on prescribed environmental matters under its biodiversity offset legislation, which includes the Environmental Offsets Act 2014, the Environmental Offsets Regulations 2014, and the statutory Queensland Environmental Offsets Policy (Version 1.6): June 2018 (Department of the Environment and Science, 2018). The Department of Environment and Science (DES) administers this legislation.

Qld legislation and policy require biodiversity offsets to be "like-for-like" (E_10) and to be focused only on listed matters (termed as prescribed environmental matters) (E_1, E_3). This legislative framework requires no net loss (E_5) as part of the described biodiversity offset 
principles, and allows for staged (E_11), advanced (E_9) and delegated (E_7) biodiversity offsets. It includes an appeal process for developers (S_1) and for communities (S_2) through an application for an internal review. DES provide three calculators to assist in the development of suitable biodiversity offsets as required by the Qld legislation and policy: the Financial Settlement Calculator for financial settlement offsets, and the Impact Matters and Offset Matters calculators to assist in site assessment (E_6). The financial impact on developers is considered through the Financial Settlement Calculator (Ec_2) and allowance is made for financial contributions in lieu of biodiversity offsets (Ec_3).

\subsubsection{South Australia (SA)}

Biodiversity offsets in SA are required to compensate for the clearing of terrestrial native vegetation. This is administered by the Native Vegetation Council under the Native Vegetation Act 1991 and the Native Vegetation Regulations 2017. Under these legislative instruments, developers are required to ensure a significant environmental benefit to counterbalance vegetation loss (E_2). Further guidance is provided to developers removing scattered trees under the non-statutory Policy for calculating a Significant Environmental Benefit under the Native Vegetation Act 1991 and the Native Vegetation Regulations 2017 (Department of Environment, Water and Natural Resources, 2017a) and the Guide for calculating a Significant Environmental Benefit under the Native Vegetation Act 1991 and the Native Vegetation Regulations 2017 (Department of Environment, Water and Natural Resources, 2017b).

The SA policy requires biodiversity offsets for the removal of native vegetation, that these biodiversity offsets are "like-for-like" (E_10) and ensure no net loss (E_5). The guidelines include biodiversity offsets calculations (E_6) and allow for biodiversity offsets to be delegated (E_7), as well as for developers to provide financial contributions in lieu of biodiversity offsets (Ec_2). The financial impact on the developer is considered as part of the calculations for financial contributions provided in the guide. However, as this has not been considered for other types of biodiversity offsets allowed by SA, this has not been included in the analysis.

\subsubsection{Tasmania (Tas)}

Biodiversity offsets in Tas are complex in that they are required through four different mechanisms:

- The Department of Primary Industries, Parks, Water and Environment (DPIPWE) requires biodiversity offsets within the dam assessment framework under the Water Management Act 1999.

- DPIPWE also applies biodiversity offsets under the Resource Management and Planning System, which is described in the Tasmanian Natural Resource Management Framework (Department of Primary Industries, Water and Environment, 2002), and provides guidance under the Guidelines for Natural Values Surveys - Terrestrial Development Proposals (Natural and Cultural Heritage Division, 2015). 


\section{Macrothink}

- The Forest Practices Authority (FPA) requires biodiversity offsets to compensate for the loss of significant biodiversity values within forest practices plans in accordance with the Forest Practices Act 1985, the Threatened Species Protection Act 1995 and the Nature Conservation Act 2002. The FPA has produced the non-statutory Policy of the Forest Practices Authority: The use of offsets (Forest Practices Authority, 2011) to compensate for the loss of significant biodiversity values within forest practices plans. This includes the DPIPWE General Offset Principles as an attachment; however the DPIPWE guideline is no longer directly available from the DPIPWE website. Despite this confusion, this text was analysed.

- In addition to this, biodiversity offsets are also required by some local planning authorities. These have not, however, been included in the analysis.

Tas allows for flexibility in the application of biodiversity offsets and does not describe which matters are required to be offset. Indirect biodiversity offsets (E_8), as well as staging (E_1) and delegation (E_7) of biodiversity offsets, are permitted. The DPIPWE offset principles state that biodiversity offsets should be like-for-like and ensure no net loss, but this is not required, and as such has not been included in the analysis.

\subsubsection{Victoria (Vic)}

In Vic biodiversity offsets are required to compensate for the clearing of native vegetation under the Planning and Environment Act 1987, which is administered by the Department of Environment, Land, Water and Planning (DELWP). In the Biodiversity information explanatory document: measuring value when removing or offsetting native vegetation (Department of Environment, Land, Water and Planning, 2017a), DELWP have provided maps classifying areas of native vegetation to provide further guidance as to the biodiversity offsets required (E_1).

DELWP has also developed the documents Guidelines for the removal, destruction or lopping of native vegetation (Department of Environment, Land, Water and Planning, 2017b) and A quick comparison of first party and third party offset sites (Department of Environment, Land, Water and Planning, 2017c), which further describe biodiversity offset requirements. Vic requires two types of biodiversity offsets; species offsets, that require a like-for-like offset, and general offsets, that must be within the same area as the vegetation removed (E_10). Under these documents, biodiversity offsets ensure no net loss of biodiversity through the use of multipliers for species (x2) and general (x1.5) offsets (E_5). However, biodiversity offsets may be delegated (E_7) and developers may trade permits (Ec_1) through the Native Vegetation Credit Register. The guideline provides definitions for matters to be biodiversity offset (E_1), as well as a biodiversity offsets calculations (E_6).

\subsubsection{Western Australian (WA)}

The WA Environmental Protection Authority (WA EPA) has also developed a non-statutory guideline for biodiversity offsets, the WA Environmental Offset Guidelines: August 2014 (Environmental Protection Authority, 2014). The guideline provides further guidance to developers that are required to implement biodiversity offsets under the WA Environmental 
Offsets Policy 2011 (Government of Western Australia, 2011), which has been made statutory under the Environmental Protection Act 1986 (the EP Act). Biodiversity offsets primarily arise under this legislative framework either through the assessment of significant development proposals, such as extractive industries by the WA EPA, or through the consideration of vegetation clearing permits by the Parks and Wildlife Service (Foster, 2013).

Biodiversity offsets are required for significant residual impacts on environmental matters, such as rare and endangered plants and animals, areas within the formal conservation reserve system, important environmental systems and species that are protected under international agreements, and areas that are already defined as being critically impacted in a cumulative context (Environmental Protection Authority, 2014).

The WA policy and guideline require that biodiversity offsets ensure no net loss of biodiversity (E_5) and to be "like-for-like" (E_10). Delegation (E_7) and staging (E_11) of biodiversity offsets is allowed, as are advanced (E_9) and indirect (E_8; termed "Research projects") biodiversity offsets. WA has an appeal processes for both developers (S_1) and communities ( $\mathrm{S} \_2$ ) and requires that community consultation $\left(\mathrm{S} \_3\right)$ be undertaken by developers. Financial payments in lieu of biodiversity offsets are also permitted (Ec_2).

\subsection{Aspects of Policy and Legislation}

Eleven environmental, three social and three economic considerations were present in the legislation, policies and published guidelines for the various Australian jurisdictions (Table 2). Specifically, the environmental considerations included definitions of matters to be offset and provision of a biodiversity offsets calculator(s) that developers may use to assist in the planning of acceptable biodiversity offsets. Environmental requirements were found for matters specifically listed under legislation (Cwlth, ACT, NSW, Qld, Vic), and/or only for the clearing of native vegetation (SA, Vic), delivery of biodiversity offsets within specific timeframes (ACT), overall no net loss of biodiversity (Cwlth, ACT, Qld, SA, Vic), and that biodiversity offsets must be "like-for-like" (Cwlth, ACT, NSW, Qld, SA, Vic, WA). Delegation of biodiversity offsets to third parties by developers was allowed by all jurisdictions requiring biodiversity offsets, and staging of biodiversity offsets are allowed by some jurisdictions (Cwlth, ACT, NSW, Qld, Tas, WA). In addition, some jurisdictions (Cwlth, ACT, Qld, WA) also allowed for advanced biodiversity offsets, in which projects that have been previously undertaken by a developer and determined in some way to be beneficial to biodiversity are used to offset impacts that are occurring or will occur in the future. Indirect biodiversity offsets were also allowed by some jurisdictions (Cwlth, ACT, NSW, Tas, WA), in the form of projects that contribute to the overall knowledge of a matter without directly providing protection.

Social considerations included requirements for developers to consult with the community (ACT, WA) and allow appeal processes for developers and/or members of affected communities (Qld, WA).

Economic considerations such as the financial impact of the biodiversity offset on developers (Cwlth, NSW, Qld), allowing developers to trade permits (NSW, Vic), and allowing 


\section{Macrothink}

developers to provide a financial contribution to the government for conservation in lieu of providing biodiversity offsets (NSW, Qld, SA, WA) were included by some jurisdictions.

Legislative inclusions varied among jurisdictions (Table 2). The delegation of biodiversity offsets to third party providers (E_7) and the requirement for biodiversity offsets to be "like-for-like" (E_10) were the most commonly included considerations with eight and seven jurisdictions requiring these respectively (Table 2). The consideration that was least frequently required for biodiversity offsets was for delivery within specified timeframes (E_4); with only one jurisdiction including this component. Inclusion of appeal processes for developers (S_1) and communities (S_2), as well as the requirement for biodiversity offsets for the removal of all native vegetation (E_2) and the allowance of tradeable permits (Ec_1) were also poorly considered, with these only occurring in two jurisdictions each (Table 2).

The legislation and policies for Qld were the most comprehensive, including 12 considerations across environmental and economic aspects. The ACT and NSW had the second most considerations with 11. The NT included no considerations and Tas had the second least with three, despite having biodiversity offset requirements spread across several different legislative instruments.

ACT and Cwlth included the largest number of environmental considerations, with 10 and 9 respectively, while Tas included the least with three. WA included the most social considerations with three, while Cwlth, NSW, SA, Tas and Vic did not include social considerations. NSW included three economic considerations; Tas and ACT did not have any economic considerations.

Table 2. Environmental, social and economic considerations identified in the legislation and /or policy of each jurisdiction

\begin{tabular}{|c|c|c|c|c|c|c|c|c|c|c|c|c|}
\hline & Code & Consideration & Cwlth & $\mathrm{ACT}$ & NSW & NT & Qld & SA & Tas & Vic & WA & Total \\
\hline \multirow{11}{*}{ 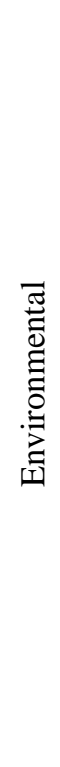 } & E_1 & $\begin{array}{c}\text { Includes definitions of } \\
\text { matters to be offset }\end{array}$ & 1 & 1 & 1 & 0 & 1 & 0 & 0 & 1 & 0 & 4 \\
\hline & E_2 & $\begin{array}{l}\text { Required for all native } \\
\text { vegetation removal }\end{array}$ & 0 & 0 & 0 & 0 & 0 & 1 & 0 & 1 & 0 & 2 \\
\hline & E_3 & Required for listed matters & 1 & 1 & 1 & 0 & 1 & 0 & 0 & 0 & 0 & 4 \\
\hline & E_4 & $\begin{array}{l}\text { Requires delivery within } \\
\text { specified timeframes }\end{array}$ & 0 & 1 & 1 & 0 & 0 & 0 & 0 & 0 & 0 & 2 \\
\hline & E_5 & $\begin{array}{c}\text { Requires no net loss of } \\
\text { biodiversity }\end{array}$ & 1 & 1 & 0 & 0 & 1 & 1 & 0 & 1 & 0 & 5 \\
\hline & E_6 & $\begin{array}{c}\text { Includes an offsets } \\
\text { calculator }\end{array}$ & 1 & 1 & 1 & 0 & 1 & 1 & 0 & 1 & 0 & 6 \\
\hline & E_7 & $\begin{array}{c}\text { Allows offsets to be } \\
\text { delegated }\end{array}$ & 1 & 1 & 1 & 0 & 1 & 1 & 1 & 1 & 1 & 8 \\
\hline & E_8 & Allows indirect offsets & 1 & 1 & 1 & 0 & 0 & 0 & 1 & 0 & 1 & 5 \\
\hline & E_9 & Allows advanced offsets & 1 & 1 & 0 & 0 & 1 & 0 & 0 & 0 & 1 & 4 \\
\hline & E_10 & $\begin{array}{l}\text { Requires "like-for-like" } \\
\text { offsets }\end{array}$ & 1 & 1 & 1 & 0 & 1 & 1 & 0 & 1 & 1 & 7 \\
\hline & E_11 & Allows offsets to be staged & 1 & 1 & 1 & 0 & 1 & 0 & 1 & 0 & 1 & 6 \\
\hline \multirow{2}{*}{ 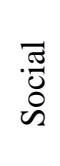 } & S_1 & $\begin{array}{c}\text { Includes an appeal process } \\
\text { for developers }\end{array}$ & 0 & 0 & 0 & 0 & 1 & 0 & 0 & 0 & 1 & 2 \\
\hline & S_2 & $\begin{array}{l}\text { Includes an appeal process } \\
\text { for community members }\end{array}$ & 0 & 0 & 0 & 0 & 1 & 0 & 0 & 0 & 1 & 2 \\
\hline
\end{tabular}




\begin{tabular}{|c|c|c|c|c|c|c|c|c|c|c|c|c|}
\hline & S_3 & $\begin{array}{l}\text { Requires community } \\
\text { consultation }\end{array}$ & 0 & 1 & 0 & 0 & 0 & 0 & 0 & 0 & 1 & 2 \\
\hline \multirow{3}{*}{ 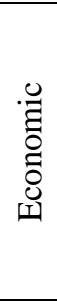 } & Ec_1 & Allows tradeable permits & 0 & 0 & 1 & 0 & 0 & 0 & 0 & 1 & 0 & 2 \\
\hline & Ec_2 & $\begin{array}{c}\text { Allows for a financial } \\
\text { contribution in lieu of an } \\
\text { offset }\end{array}$ & 0 & 0 & 1 & 0 & 1 & 1 & 0 & 0 & 1 & 4 \\
\hline & Ec_3 & $\begin{array}{c}\text { The financial impact of } \\
\text { offset on developer is taken } \\
\text { into account }\end{array}$ & 1 & 0 & 1 & 0 & 1 & 0 & 0 & 0 & 0 & 3 \\
\hline \multicolumn{3}{|r|}{ Total } & 10 & 11 & 11 & 0 & 12 & 6 & 3 & 7 & 9 & \\
\hline
\end{tabular}

\subsection{Similarity Analysis}

According to the statistical analysis, ACT and Cwlth were the most similar in offsetting capability, with a similarity of 75\% (Table 3, Figure 2). However QLD and NSW were also moderately similar to both ACT (>50\% similarity) and Cwlth (>60\% similarity). Vic and SA were also moderately similar, with similarities greater than $60 \%$.

NT was the least similar to the other jurisdictions with a similarity of $0 \%$ due to the fact that NT does not have biodiversity offsets policy or legislation in place and cannot require biodiversity offsets. To prevent skewing of results, NT was removed from further analysis (Table 3, Figure 2).

Of the other jurisdictions, Vic and Tas were the least similar with less than $11 \%$ similarity (Table 3, Figure 2). In fact, Tas had a low similarity to all jurisdictions, consistently demonstrating the least similarity (Table 3, Figure 2).

Table 3. Similarity matrix showing the percentage similarity between the biodiversity offsets policy and legislation of each jurisdiction based on the aspects analyzed

\begin{tabular}{|l|r|r|r|r|r|r|r|r|}
\hline & Cwlth & \multicolumn{1}{|c|}{ ACT } & \multicolumn{1}{l|}{ NSW } & \multicolumn{1}{l|}{ Qld } & \multicolumn{1}{l|}{ SA } & Tas & \multicolumn{1}{l|}{ Vic } & WA \\
\hline Cwlth & 100.00 & 75.00 & 61.54 & 69.23 & 33.33 & 30.00 & 41.67 & 35.71 \\
\hline ACT & 75.00 & 100.00 & 57.14 & 53.33 & 30.77 & 27.27 & 38.46 & 42.86 \\
\hline NSW & 61.54 & 57.14 & 100.00 & 53.33 & 30.77 & 27.27 & 38.46 & 33.33 \\
\hline Qld & 69.23 & 53.33 & 53.33 & 100.00 & 38.46 & 15.38 & 35.71 & 50.00 \\
\hline SA & 33.33 & 30.77 & 30.77 & 38.46 & 100.00 & 12.50 & 62.50 & 25.00 \\
\hline Tas & 30.00 & 27.27 & 27.27 & 15.38 & 12.50 & 100.00 & 11.11 & 33.33 \\
\hline Vic & 41.67 & 38.46 & 38.46 & 35.71 & 62.50 & 11.11 & 100.00 & 14.29 \\
\hline WA & 35.71 & 42.86 & 33.33 & 50.00 & 25.00 & 33.33 & 14.29 & 100.00 \\
\hline
\end{tabular}




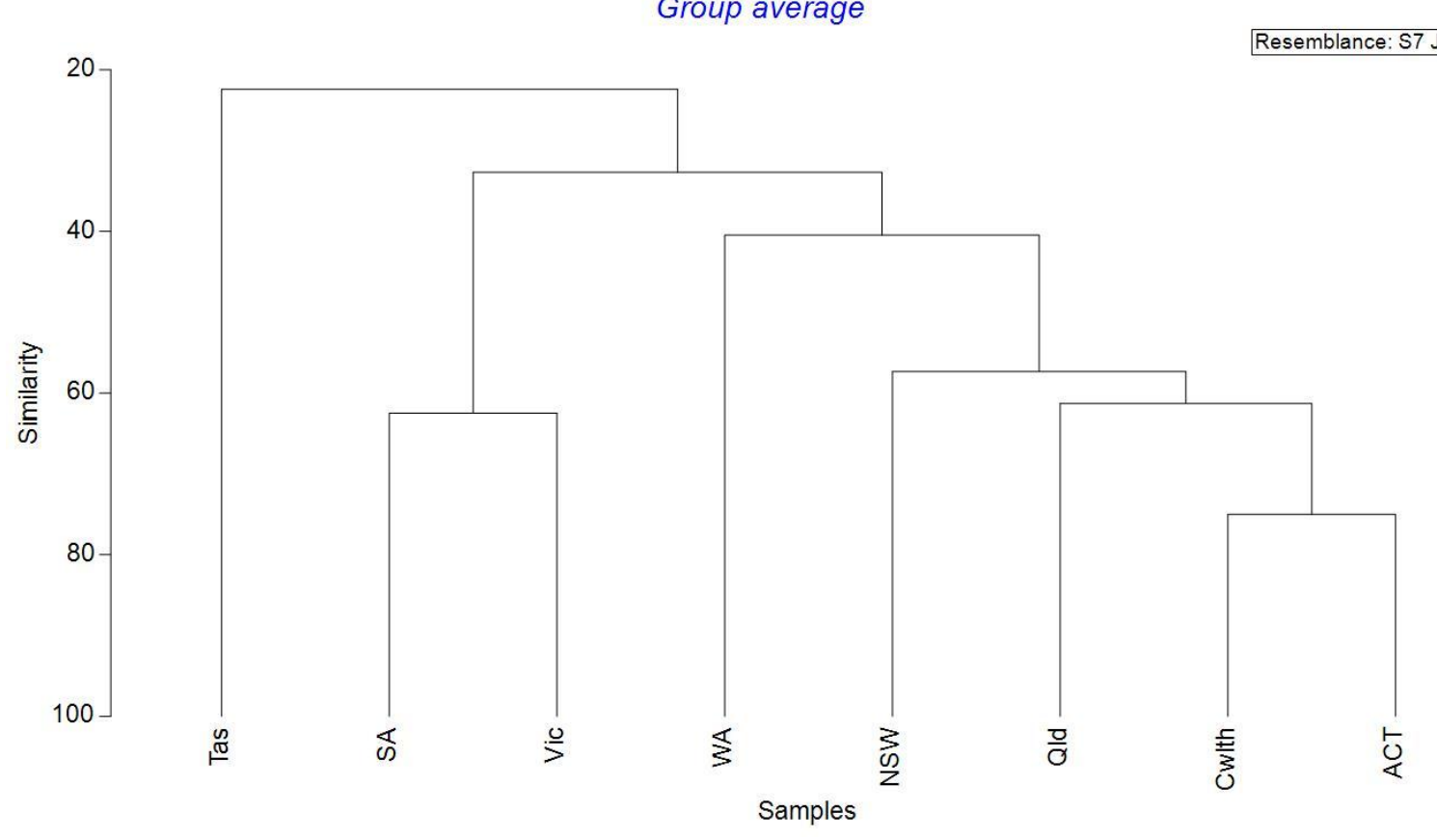

Figure 2. Cluster analysis dendrogram depicting similarities between all jurisdictions except for NT

\section{Discussion}

This study highlights the considerable inconsistencies and incompleteness in biodiversity offsets policy and legislation across Australian jurisdictions, with no jurisdiction including all environmental, social and economic considerations found. The consequence of this variation is that some states/territories have the capacity to elicit clear requirements for biodiversity offsets, whilst others do not. In addition, it was apparent that there is insufficient consideration of social and economic aspects of sustainability in relation to biodiversity offsets, with few considerations recorded and few jurisdictions including the considerations found. Clearly there is need for consolidation of legislation and policies across Australian in order to ensure that the application of biodiversity offsets is not contradictory to the goals of sustainable development.

\subsection{Similarity among Jurisdictions}

Australian jurisdictions, other than NT, included the environmental aspect of sustainability in their legislation, policies and published guidelines. All jurisdictions, other than Tas, also considered at least one other aspect (social or economic). The consideration of these aspects varied with the jurisdictions broadly organised into four clusters: 1) Cwlth, ACT, NSW and Qld, 2) SA and Vic, 3) WA and 4) Tas. The variability in Australia's biodiversity offset requirements is primarily because there are no nationally or internationally recognised standards for biodiversity offsets (Benabou, 2014). Further, the Cwlth has restricted its responsibility for MNES under the HoA (Macintosh, 2015). While the states and territories have responsibility for the whole of the environment within their respective regions, how this is achieved is discretionary (Macintosh, 2015). Due to the democratic nature of the political 
process in Australia, the way this responsibility is actioned is almost certainly reflective of the political climate of each jurisdiction. This has further implications in terms of equity between developers and communities. The Cwlth allows state and territory imposed biodiversity offsets to contribute towards the EPBC Act required offsets package if it also offsets impacts to MNES (Department of Sustainability, Environment, Water, Population and Communities, 2012a). As such, with states and territories having different biodiversity offset requirements in place, the Cwlth may be applying offsets inconsistently, potentially causing social and economic inequities.

The objectives between State and Territory environmental legislation and policy also differed with different jurisdictions, requiring biodiversity offsets for different matters. SA and Vic require biodiversity offsets only for removal of native vegetation, while Cwlth, ACT and Qld require biodiversity offsets for impacts on listed species. The remaining states (NSW, Tas, WA) require biodiversity offsets for the protection of the environment more broadly. This is likely a reflection of politics, as legislation is driven by the needs of political parties to represent the concerns of their constituents. However, the evident disparity among states and territories regarding matters that are protected is of concern as it has the potential to enable biodiversity loss. This may be particularly important for species that have broad home ranges crossing jurisdictional boundaries and for migratory species. In addition, having jurisdictions with different biodiversity offset requirements could result in inequitable outcomes (Bull et al., 2013). While it might be argued that the Cwlth has a responsibility to fill gaps in environmental protection, the EPBC Act does not achieve this. MNES includes listed species, which must have already have been assessed as having a threatened conservation status (e.g. vulnerable), and migratory species. The conservation status of a species is, however, based on available research, and, as such, many species, particularly those with a paucity of current information on life history, ecology and/or population status, may be missed. This focus on listed species may also miss provisioning species that support these listed species, allowing indirect threats on listed species to occur.

An indirect source of inconsistency in approach relates to how biodiversity offsets are required under legislation. Excluding Qld, which has specific biodiversity offset legislation, and NT, with no biodiversity offset legislation or policies, all biodiversity offset requirements of Australian jurisdictions are described in policies. While for ACT and WA these policies are statutory, for the remainder of the states and territories these are non-statutory documents. This means that biodiversity offset requirements are guidelines only, and instead are required at the discretion of the governing jurisdiction.

Even where policies are statutory, there is now a legal precedent where these have been found to be discretionary. The Roe 8 development (a road extension project proposed for the use by heavy transportation, primarily trucks, in order to bypass inner suburban streets when transporting freight to and from Fremantle Port in Western Australia) was granted conditional environmental approval to clear approximately 97.8 hectares of native vegetation within a 167 hectares development envelope by the WA Minister for the Environment, Hon Albert Jacob MP, 5 July 2015. This highly controversial project was the subject of several appeals, most notably that the WA EPA had been legally unreasonable in ignoring its own policies 
when approving the project (Save Beeliar Wetlands (Inc) -v- Jacob [2015] WASC 482). Ultimately, however, the high court found that the WA EPA was under no legal obligation to consider its policies, and was therefore free to grant approvals on other considerations (Jacob-v-Save Beeliar Wetlands (Inc) [2016] WASCA 126). This sets an important legal precedent in Australian environmental regulation, and in particular has potential implications for biodiversity offsets which are primarily described under policies.

Another source of dissimilarity in biodiversity offsets between the jurisdictions may be in the application of biodiversity offsets by regulators. Although this concept was not assessed in this study, it is foreseeable that discretion used in the application of biodiversity offset requirements could cause further dissimilarity not only between jurisdictions, but perhaps even within a jurisdiction.

\subsection{Consistency in Biodiversity Offsets}

Greater consistency in the requirements for biodiversity offsets would address gaps in protection and equity between developers/communities. Furthermore it may create greater benefits for the environment by allowing developers to build complementary biodiversity offset programs across jurisdictions to provide better outcomes. Martin, Evans, Rice, Lodhia, and Gibbons (2016) found this to be a key priority when interviewing relevant stakeholders from various sectors including governments, business, NGOs and individuals.

Globally, there is also a case for a consistent approach to biodiversity offsets. It may be argued that this is evidenced by the success of BBOP, an organisation with more than 80 members, including developers, service providers, governments, conservation groups and individuals. BBOP shares information on a best practice approach to biodiversity offsets that, in effect, would achieve consistency between those using the BBOP approach. While developers may strive for best practice and to follow a consistent approach to biodiversity offsets, they must also meet the requirements that are imposed by jurisdictions relevant to their developments. As such, it is unlikely that a consistent approach to biodiversity offsets will be broadly adopted without a consistent approach being required within legislation and policies between jurisdictions.

Although legislation and impetus differs among countries, countries developing biodiversity offset requirements generally look to others to find out how to develop and implement them. Reviews have been published comparing the environmental regulation and market based instruments for biodiversity offsets that are used in Australia to countries such as Uzbekistan and South Africa (Bull \& Brownlie, 2015; Midgley, 2015). Additionally, countries such as the United Kingdom have based their biodiversity offset requirements on examples from Australia (Carver, 2015). In this way, Australia may have the ability to influence the concept of biodiversity offsets globally and to drive biodiversity offsets policy to better ensure sustainability of development.

In recent times, there has been a move to improve consistency in biodiversity offsets policy and legislation across Australian jurisdictions. In 2012, COAG agreed to reform regulation to reduce the duplication of environmental requirements (including biodiversity offsets) and 
double-handling of environmental assessments of development applications (Department of Sustainability, Environment, Water, Population and Communities, 2012c). This agreement resulted in a commitment for the Cwlth to delegate its environmental assessments and approvals to the states and territories by way of bilateral agreements (Department of Sustainability, Environment, Water, Population and Communities, 2012d). While this is a step in the right direction in regards to improving the consistency of biodiversity offsets, these agreements only apply to matters protected by the EPBC Act. Consequently, this move will not address the disparity in the protection of environmental matters using biodiversity offsets between states and territories. Further, with a paucity of appropriate social and economic considerations in the EPBC Act, it will not appropriately address the other aspects of sustainable development in relation to biodiversity offsets. Additionally, uptake to date has been poor, with bilateral agreements in effect for the assessment of MNES in place for all states and territories, but not for the approval of MNES. In practice, this means that states and territories have the delegated ability to assess MNES on behalf of the Cwlth, but approval and the requirements for conditions, including biodiversity offsets, remains at the discretion of the Cwlth.

\subsection{Biodiversity Offset and Sustainability}

Ideally, jurisdictions that use biodiversity offsets to allow developments to go ahead should ensure sustainability by including biodiversity offset requirements that appropriately encompass environmental, social and economic aspects. In fact, as environmental legislation in Australia requires consideration of sustainable development through interpretation (Macintosh, 2015), consideration of the environmental, social and economic aspects of sustainability is required relation to biodiversity offsets. However, biodiversity offsets policy and legislation in Australia was found to be heavily weighted towards environmental components, with 11 of the total of 18 components analysed being environmental. This is likely a reflection of the requirement for biodiversity offsets to compensate for environmental impacts under environmentally focussed legislation. Although social and economic aspects must be considered in the assessment process, without explicit mention of these aspects in legislation and policy, this will be discretionary and is not reflective of a balanced approach to sustainable development. To ensure that biodiversity offsets are applied fairly and consistently, legislation and policies should comprehensively include environmental, social and economic considerations and ensure that the definition and application of significance criteria for each consideration is applied consistently. Without this, the potential to unfairly impact developers and communities, as well as the introduction of unnecessary risks to the environment, will continue.

Both developments and biodiversity offsets can pose substantial social and economic risks if not appropriately considered. The change of use of an area from one purpose (such as a public open space) in order to be set aside for a development can have societal impacts through restrictions to recreational services (e.g. fishing, hiking, etc.), visual amenity, pollution concerns and removal of ecosystem services. As a consequence, there may be loss of income from ecosystem services impacted by a development, thereby introducing economic concerns to communities. In addition to this, the placement of the biodiversity 
offset could cause similar negative impacts to society and the economy, for example by 'locking-away' for conservation certain ecological resources that were used by a community (Ghosh, 2017).

Additionally, economic components regarding the cost/benefit of the biodiversity offset approach should be considered to ensure that developers are not unfairly disadvantaged and/or the benefits to communities of development (economically or through the access to further services) are not inequitable. As such, not only should environmental, social and economic components be considered for developments, all three aspects should also be considered for biodiversity offsets.

Theoretically, a consistent approach to biodiversity offsets could allow developers more flexibility to achieve "like-for-like" by permitting biodiversity offsets in one area to be compensated for in another jurisdiction. Care would need to be taken, however, to ensure that this did not create social and economic inequity by the displacement of ecosystems services and or other associated benefits (jobs, employment, visual aesthetic etc.) that could come from biodiversity offsets, bearing in mind that for practical purposes (cost, zoning/land tenure, boundary effects etc.) biodiversity offsets are often not in the direct vicinity of the development. Further research into which environmental, social and economic considerations should be applied and incorporated into biodiversity offset regulation would ensure that biodiversity offsets are effective, fair and equitable across jurisdictions.

\subsection{The Role of the Commonwealth}

The Cwlth has the overarching responsibility under the external affairs provision of the Constitution and Australia's ratification of the CBD to ensure sustainable use of all species. This allows the Cwlth the ability to override the states and territories in regards to the protection of the environment (Peel \& Godden, 2005). The EPBC Act also requires the Cwlth to ensure sustainable development and that the principles of sustainable development must be considered in regards to determinations under the EPBC Act (Fallding, 2014; Macintosh, 2015; Peel \& Godden, 2005). However, currently this is open to much interpretation as the EPBC Act refers to 'likely significant impacts', which are not defined, reducing transparency of matters assessed and compensation required (Macintosh, 2015; Peel \& Godden, 2005). The analysis conducted in this study found that the Cwlth included environmental components to ensure sustainable use, such as requirements for no net loss of biodiversity and for biodiversity offsets to be like-for-like. However, the EPBC Act restricts the role of the Cwlth to protection of MNES, as agreed in the HoA, which has been criticised as being unnecessarily restrictive (Peel \& Godden, 2005).

While the EPBC Act restricts the role of the Cwlth, this could be changed as the Cwlth has the power to enact a much broader role in terms of the environment (Peel \& Godden, 2005) and because the HoA is an agreement, meaning that it is non-legally binding. Consequently the Cwlth could extend its regulation to ensure that there are no gaps in the protection of species. This could, however, create conflict with the states and territories. The impetus behind the HoA is not for comprehensive environmental protection, but rather to avoid conflict between the Cwlth and the states and territories on environmental matters. The states 
and territories have a long history of resisting any interference of the Cwlth in their affairs in relation to the environment. This is best exemplified by the Tasmanian Dam Case in 1983, where the then Premier of Tasmania Robin Gray, very publically defied an order of the Cwlth to halt construction of a dam on the Gordon River, which is situated within a World Heritage Area. In relation to biodiversity offsets legislation, development of a specific COAG council dedicated to the environment could be a solution that would allow consistency between jurisdictions to be obtained.

The analysis conducted in this study found that the Cwlth only included one social component and no economic components. The Cwlth approves developments under the EPBC Act on the basis that biodiversity offsets are undertaken and has a commitment to ensure Australia meets its obligations to sustainable development as a signatory to the CBD, as well as Agenda 21, the Rio Declaration on Environmental Development and the 2030 Agenda for Sustainable Development. Therefore in addition to the environment, the Cwlth should include social and economic aspects for biodiversity offsets regulation. Currently, all determinations under the EPBC Act require consideration of the principles of sustainable development, meaning that the Minister must have regard to all social and economic issues. However, with the scope of the EPBC Act restricted to direct or indirect impacts on MNES, the Minister can only consider certain environmental issues (Macintosh, 2015; Peel \& Godden, 2005). As the requirement for sustainable development is not encapsulated in legislation specifically, further research would need to be undertaken as to how this is applied. With this legal ambiguity, however, it is likely that the application the EPBC Act is inconsistent. The restriction of the EPBC Act to consider only listed species and communities and not all of biodiversity is contrary to the principles of sustainable development and means that the EPBC Act in its current state is contradictory and can not be fully implemented (Macintosh, 2015). The EPBC Act should be revised or replaced with new legislation that incorporates these requirements in order to ensure that the principles of sustainable development are adequately considered for all developments with significant impacts, and to ensure that all of the environment is protected. Further, a comprehensive framework for biodiversity is needed with clarity of roles and responsibilities at all three levels of government (Fallding, 2014).

\section{Conclusion}

Approval of developments is often contingent upon the implementation of appropriate biodiversity offsets. As such, biodiversity offsets should consider environmental, social and economic aspects to ensure that the developments approved by regulators are consistent with Australia's obligations to sustainable development. Currently inconsistencies in biodiversity offsets policy and legislation mean that species may be vulnerable to loss and environmental degradation may occur. In addition, social aspects, such as ecosystem services, are not being considered and financial cost for developers and communities may not be applied equitably. The focus of legislation and policy on environmental aspects, without adequately considering economic and social aspects of biodiversity offsets means that Australia may be remiss in their international obligations related to sustainable development. 
Australia could improve its use of biodiversity offsets to assist in the achievement of sustainable development by ensuring that environmental, social and economic aspects of sustainability are considered in a balanced way across all jurisdictions. As the Cwlth has the responsibility for implementing the $\mathrm{CBD}$ and ensuring the sustainable use of species, consistency in the approach to biodiversity offsets that ensures sustainable development will need to be driven by the Cwlth. With appropriate support through COAG, Australia could use biodiversity offsets to ensure effective sustainable development, a notable achievement that could be adopted by other countries globally.

\section{Acknowledgement}

The authors acknowledge T. Meagher, G. Coupland, D. Abdo and J. McDonald for advice and reviews.

This research forms part of a $\mathrm{PhD}$ submission and has been funded by an Australian Government Research Training Program Scholarship.

Declarations of interest: none. This research did not receive any specific grant from funding agencies in the public, commercial, or not-for-profit sectors.

\section{References}

ACT Government Environment and Planning (2015). ACT Environmental Offsets Policy. Canberra, ACT: ACT Government Environment and Planning. Retrieved from http://www.environment.act.gov.au/cpr/environmental-offsets-policy

Ali, M., Kennedy, C. M., Kiesecker, J., \& Geng, Y. (2018). Integrating biodiversity offsets within Circular Economy policy in China. Journal of Cleaner Production, 185, 32-43. http://dx.doi.org/10.1016/j.jclepro.2018.03.027

Allen, C., Metternicht, G., \& Wiedmann, T. (2018). Prioritising SDG targets: Assessing baselines, gaps and interlinkages. Sustainability Science.

https://doi.org/10.1007/s11625-018-0596-8

Benabou, S. (2014). Making Up for Lost Nature? A Critical Review of the International Development of Voluntary Biodiversity Offsets. Environment and Society: Advances in Research, 5, 103-123. http://dx.doi.org/10.3167/ares.2014.050107

Bull, J. W., \& Brownlie, S. (2015). The transition from No Net Loss to a Net Gain of biodiversity is far from trivial. Oryx, 1-7. http://dx.doi.org/10.1017/s0030605315000861

Bull, J. W., Suttle, K. B., Gordon, A., Singh, N. J., \& Milner-Gulland, E. J. (2013). Biodiversity offsets in theory and practice. Oryx, 47(03), 369-380.

http://dx.doi.org/10.1017/s003060531200172x

Burgin, S. (2008). BioBanking: an environmental scientist's view of the role of biodiversity banking offsets in conservation. Biodiversity and Conservation, 17(4), 807-816.

http://dx.doi.org/10.1007/s10531-008-9319-2

Burton, M., Rogers, A., \& Richert, C. (2016). Community acceptance of biodiversity offsets: 
evidence from a choice experiment. Australian Journal of Agricultural and Resource Economics, 61(1), 95-114. http://dx.doi.org/10.1111/1467-8489.12151

Business and Biodiversity Offsets Programme (2018). Mitigation Hierarchy [Report]. [Online] Available: http://bbop.forest-trends.org/pages/mitigation_hierarchy

Carver, L. (2015). Measuring the value of what? An ethnographic account of the transformation of 'Nature' under the DEFRA biodiversity offsetting metric (LCSV working paper series no. 11). Manchester, U.K.: The Leverhulme Centre for the Study of Value.

Clarke, K. R., Gorley, R. N., Somerfield, P. J., \& Warwick, R. M. (2014). Change in marine communities: an approach to statistical analysis and interpretation (3rd edition). Plymouth, UK: PRIMER-E.

Coggan, A., Buitelaar, E., Bennett, J., \& Whitten, S. M. (2013). Transferable Mitigation of Environmental Impacts of Development: Two Cases of Offsets in Australia. Journal of Environmental Policy \& Planning, 15(2), 303-322.

http://dx.doi.org/10.1080/1523908x.2013.781350

Commonwealth of Australia (1992). Intergovernmental Agreement on the Environment. [WWW page]. URL http://www.environment.gov.au/about-us/esd/publications/intergovernme ntal-agreement

Council of Australian Governments (1997). Heads of agreement on Commonwealth and State roles and responsibilities for the Environment. [WWW page]. [Online] Available: http://www.environment.gov.au/resource/heads-agreement-commonwealth-and-state-roles-an d-responsibilities-environment

Department of the Environment and Energy (2018). EPBC Act environmental offsets policy. Canberra, ACT: Department of the Environment and Energy. [Online] Available: http://www.environment.gov.au/epbc/publications/epbc-act-environmental-offsets-policy

Department of Environment and Science (2016). Queensland Environmental Offsets Policy: V. 1.6. Brisbane, Queensland: Department of Environment and Science. [Online] Available: https://www.ehp.qld.gov.au/assets/documents/pollution/management/offsets/offsets-policyv16.pdf

Department for Environment and Water (2017). Offsetting [WWW page]. [Online] Available: https://www.environment.sa.gov.au/topics/native-vegetation/offsetting

Department of Environment, Water and Natural Resources (2017a). Policy for calculating a Significant Environmental Benefit under the Native Vegetation Act 1991 and the Native Vegetation Regulations 2017. Adelaide, South Australia: Department of Environment, Water and Natural Resources. [Online] Available:

https://www.environment.sa.gov.au/topics/native-vegetation/offsetting

Department of Environment, Water and Natural Resources (2017b). Guide for calculating a Significant Environmental Benefit under the Native Vegetation Act 1991 and the Native Vegetation Regulations 2017. Adelaide, South Australia: Department of Environment, 
Water and Natural Resources. [Online] Available:

https://www.environment.sa.gov.au/topics/native-vegetation/offsetting

Department of Environment, Land, Water and Planning (2017a). Biodiversity information explanatory document: measuring value when removing or offsetting native vegetation. Melbourne, Victoria: Department of Environment, Land, Water and Planning. [Online] Available:

https://www.environment.vic.gov.au/_data/assets/pdf_file/0025/91267/Biodiversity-informat ion-explanatory-document-Measuring-value-when-removing-or-.pdf

Department of Environment, Land, Water and Planning (2017b). Guidelines for the removal, destruction or lopping of native vegetation. Melbourne, Victoria: Department of Environment, Land, Water and Planning. [Online] Available:

https://www.environment.vic.gov.au/_data/assets/pdf_file/0021/91146/Guidelines-for-the-re moval,-destruction-or-lopping-of-native-vegetation,-2017.pdf

Department of Environment, Land, Water and Planning (2017c). A quick comparison of first party and third party offset sites. Melbourne, Victoria: Department of Environment, Land, Water and Planning. [Online] Available:

https://www.environment.vic.gov.au/_data/assets/pdf_file/0023/329450/Info-sheet-A-quickcomparison-of-first-party-and-third-party-offset-sites.pdf

Department of Primary Industries, Water and Environment (2002). Tasmanian Natural Resource Management Framework. Hobart, Tasmania: Department of Primary Industries, Water and Environment. [Online] Available:

http://dpipwe.tas.gov.au/Documents/ReportNoPics.pdf

Department of Sustainability and the Environment (2003). Victoria's native vegetation management: a framework for action. Victoria: Department of Sustainability and the Environment. [Online] Available:

https://www.environment.vic.gov.au/_data/assets/pdf_file/0021/90363/Native_Vegetation_ Management_-_A_Framework_for_Action.pdf

Department of Sustainability, Environment, Water, Population and Communities (2012a). Environment Protection and Biodiversity Conservation Act 1999 Environmental Offsets Policy. Canberra, ACT: Department of Sustainability, Environment, Water, Populations and Communities. Retrieved from https://www.environment.gov.au/epbc/publications/epbc-a ct-environmental-offsets-policy

Department of Sustainability, Environment, Water, Population and Communities (2012b). How to use the offsets assessment guide. Canberra, ACT: Department of Sustainability, Environment, Water, Populations and Communities. [Online] Available: https://www.environment.gov.au/system/files/resources/12630bb4-2c10-4c8e-815f-2d7862bf 87e7/files/offsets-how-use.pdf

Department of Sustainability, Environment, Water, Population and Communities (2012c). Statement of Environmental and Assurance Outcomes. Canberra, ACT: Department of 
Sustainability, Environment, Water, Populations and Communities. [Online] Available: http://www.environment.gov.au/resource/draft-framework-standards-accreditation-and-statem ent-environmental-and-assurance-outcomes

Department of Sustainability, Environment, Water, Population and Communities (2012d). Draft Framework of Standards for Accreditation of Environmental Approvals under the Environmental Protection and Biodiversity Conservation Act 1999. Canberra, ACT: Department of Sustainability, Environment, Water, Populations and Communities. [Online] Available: http://www.environment.gov.au/resource/draft-framework-standards-accreditationand-statement-environmental-and-assurance-outcomes

Environment, Land, Water and Planning (2018). Native vegetation [WWW page]. [Online] Available: https://www.environment.vic.gov.au/native-vegetation/native-vegetation

Environment, Planning and Sustainable Development Directorate (2018). Environmental offsets [WWW page]. [Online] Available:

https://www.environment.act.gov.au/cpr/environmental-offsets-policy

Environmental Protection Authority (2018). WA Environmental Offsets Policy and Guidelines. Perth, Western Australia: Environmental Protection Authority. [Online] Available: http://www.epa.wa.gov.au/guidelines-and-procedures/wa-environmental-offsets-policy-and-g uidelines

Environmental Protection Authority (2014). WA Environmental Offset Guidelines: August 2014. Perth, Western Australia: Environmental Protection Authority. [Online] Available: https://www.der.wa.gov.au/your-environment/offsets

Ecologically Sustainable Development Steering Committee (1992). National Strategy for Ecologically Sustainable Development. Canberra, Australian Capital Territory: Ecologically Sustainable Development Steering Committee. [Online] Available:

http://www.environment.gov.au/about-us/esd/publications/national-esd-strategy

Fallding, M. (2014). Biodiversity offsets: Practice and promise. Environmental and Planning Law Journal, 31(11), 11-33.

Forest Practices Authority (2011). The use of offsets to compensate for the loss of significant biodiversity values within forest practices plans. Hobart, Tasmania: Forest Practice Authority. [Online] Available:

http://www.fpa.tas.gov.au/_data/assets/pdf_file/0010/110611/FPA_policy_on_offsets.pdf

Foster, D. (2013, April). Biodiversity offsetting for mining and energy development. Presentation at the Biodiversity Offsetting for Mining \& Energy Development Conference, Perth, Western Australia.

Ghosh, S. (2017). Compensatory Afforestation: 'Compensating' Loss of Forests or Disguising Forest Offsets?. Economic \& Political Weekly, LII(38), 67-75.

Gibson, R. B. (2009). Beyond the pillars: Sustainability assessment as a framework for effective integration of social, economic and ecological considerations in significant 
decision-making. In Sheate, W.R. (ed). Tools, Techniques and Approaches for Sustainability: Collected Writings in Environmental Assessment Policy and Management. Singapore: World Scientific Publishing Co Pte Ltd.

Government of Western Australia (2011). WA Environmental Offsets Policy. Perth, Western Australia: Government of Western Australia. [Online] Available:

https://www.der.wa.gov.au/your-environment/offsets

Moldan, B., \& Dahl, A. L. (2007). Challenges to Sustainability Indicators. In Hák, T., Moldan, B. \& Dahl, A. L. (Eds). Sustainability indicators: A scientific assessment. Washington, D.C.: Island Press.

INPEX (2012). Coastal Offsets Strategy. Perth, Western Australia: INPEX Corporation.

International Institute for Sustainable Development (2017). Topic: Sustainable development [WWW page]. [Online] Available: http://www.iisd.org/topic/sustainable-development

Kujala, H., Whitehead, A. L., Morris, W. K., \& Wintle, B. A. (2015). Towards strategic offsetting of biodiversity loss using spatial prioritization concepts and tools: A case study on mining impacts in Australia. Biological Conservation, 192, 513-521.

http://dx.doi.org/10.1016/j.biocon.2015.08.017

Lim, F. K. S., Carrasco, L. R., McHardy, J., \& Edwards, D. P. (2017). Perverse Market Outcomes from Biodiversity Conservation Interventions. Conservation Letters, 10 (5), 506-516. http://dx.doi.org/10.1111/conl.12332

Macintosh, A. (2015). The impact of ESD on Australia's environmental institutions. Australasian Journal of Environmental Management, 22(1), 33-45.

http://dx.doi.org/10.1080/14486563.2014.999724

Martin, N., Evans, M., Rice, J., Lodhia, S., \& Gibbons, P. (2016). Using offsets to mitigate environmental impacts of major projects: A stakeholder analysis. Journal of Environmental Management, 179, 58-65. http://dx.doi.org/10.1016/j.jenvman.2016.04.054

May, J., Hobbs, R. J., \& Valentine, L. E. (2017). Are offsets effective? An evaluation of recent environmental offsets in Western Australia. Biological Conservation, 206, 249-257. http://dx.doi.org/10.1016/j.biocon.2016.11.038

Midgley, D. (2015). Biodiversity offsets: Towards an effective legal framework in South Africa. South Africa: University of Cape Town.

Miller, K. L., Trezise, J. A., Kraus, S., Dripps, K., Evans, M. C., Gibbons, P., Possingham, H. P., \& Maron, M. (2015). The development of the Australian environmental offsets policy: from theory to practice. Environmental Conservation, 42(4), 306-314.

http://dx.doi.org/10.1017/s037689291400040x

Natural and Cultural Heritage Division (2015). Guidelines for Natural Values Surveys Terrestrial Development Proposals. Hobart, Tasmania: Department of Primary Industries, Parks, Water and Environment. [Online] Available: 
http://dpipwe.tas.gov.au/Documents/Guidelines\%20for\%20Natural\%20Values\%20Surveys\% 20related\%20to\%20Development\%20Proposals.pdf

Northern Territory Environmental Protection Authority (2013). Guidelines on environmental offsets and associated approval conditions. Darwin, Northern Territory: Northern Territory Environmental Protection Authority. [Online] Available:

https://ntepa.nt.gov.au/_data/assets/pdf_file/0007/287431/guideline_assessment_environme ntal_offsets.pdf

Office of Environment and Heritage (2017). Biodiversity Offsets Scheme. Sydney, NSW: Office of Environment and Heritage. [Online] Available:

https://www.environment.nsw.gov.au/biodiversity/offsetsscheme.htm

Peel, J., \& Godden, L. (2005). Australian environmental management: a 'dams' story. University of New South Wales Law Journal, 28(3), 668-695.

Pope, J., Bond, A., Hugé, J., \& Morrison-Saunders, A. (2017). Reconceptualising sustainability assessment. Environmental Impact Assessment Review, 62, 205-215.

Queensland Government (2018). Environmental Offsets: Legislation. Brisbane, Queensland: Queensland Government. [Online] Available:

https://www.qld.gov.au/environment/pollution/management/offsets

\section{Copyright Disclaimer}

Copyright for this article is retained by the author(s), with first publication rights granted to the journal.

This is an open-access article distributed under the terms and conditions of the Creative Commons Attribution license (http://creativecommons.org/licenses/by/3.0/). 